\title{
PESANTREN DAN UPAYA DERADIKALISASI AGAMA
}

\author{
Mukodi \\ Sekolah Tinggi Keguruan dan IImu Pendidikan (STKIP) PGRI Pacitan \\ e-mail:mukodi@yahoo.com
}

\begin{abstract}
The de-radicalization of Islam in Tremas Islamic boarding school was found to have its continuing momentums from generation to generation. Through cultural practices as: scientific culture, religious culture, social culture, and political culture the seeds of such de-radicalization were disseminated. However, the dynamic fluctuation of extremism both transnationally and internationally became a specific challenge. Furthermore, the massive development of Information and Communication Technology (ICT) significantly impacted on the mindset of Tremas boarding school community. Applying qualitative approach and phenomenological method, this article revealed how the religious de-radicalization in Tremas boarding school was knitted and framed in the practices of daily culture. Such practices were carried out in order to make Islamic generations may wisely behave and act. Moreover, Islam might ocupy as it should be, namely Islam as rạ̣matan li 'l-ālamīn, love peace, promoting love and affection, as well as nonviolence.

$* * *$

Deradikalisasi agama Islam di Pondok Tremas dari generasi ke generasi senantiasa menemukan momentum. Melalui praktik budaya Pondok Tremas yang meliputi: budaya keilmuan, budaya keagamaan, budaya sosial dan budaya politik benih-benih deradikalisasi agama Islam disemaikan. Namun demikian, pasang surut paham ekstremisme yang berkembang di transnasional, dan internasional menjadi tantangan tersendiri. Apalagi masifnya perkembangan media teknologi dan informatika berekses secara signifikan pada pola pikir warga Pondok Tremas. Dengan menggunakan pendekatan kualitatif, dan metode fenomenologi, artikel ini menjelaskan bagaimana deradikalisasi agama di Pondok Tremas dirajut, dan dibingkai dalam praktik-praktik budaya keseharian. Hal itu, dilakukan agar generasi Islam dapat bijak dalam bersikap dan bertindak. Lebih dari itu, agar agama Islam dapat menempati area yang semestinya, yakni agama raḥmatan li 'l'älamīn, tanpa kekerasan, cinta perdamaian, dan mengedepankan cinta kasih.
\end{abstract}

Keywords: radikalisme agama, Pondok Tremas, praktik budaya 


\section{A. Pendahuluan}

Seperti jamur di musim penghujan, radikalisasi atas nama agama dan tindak anarki berkedok SARA tumbuh kembang dengan subur di pelbagai belahan Indonesia. Kasus penolakan Ir. Basuki Tjahaja Purnama, MM -yang akrab disapa Ahok- sebagai gubenur DKI Jakarta oleh organisasi Front Pembela Islam (FPI), sekaligus menetapkan Fakhrurrozi Ishaq sebagai gubenur tandingan DKI Jakarta merupakan bukti otentik atas hal itu. ${ }^{1}$ Jika, kasus intoleransi agama ditarik garis lurus kebelakang sejak 2010 hingga 2014 jumlahnya sangat masif. Berdasarkan pantauan Moderat Muslim Society (MMS) diketahui bahwa sepanjang tahun 2010 setidaknya telah terjadi 81 kasus intoleransi.

Parahnya lagi, dari 81 kasus tersebut, sebanyak 63 kasus (80\%) adalah aksi penyerangan, penolakan rumah ibadah dan intimidasi. Kasus yang paling sering terjadi adalah penyerangan dan perusakan (24 kasus); penutupan dan penolakan rumah ibadah (24 kasus); ancaman, tuntutan, dan intimidasi (15 kasus); penghalangan kegiatan ibadah (6 kasus); diskriminasi karena keyakinan (4 kasus); pembubaran kegiatan atas nama agama (3 kasus); dan kriminalisasi paham keagamaan (3 kasus) dan pengusiran ( 2 kasus). ${ }^{2}$

Pada tahun 2011 kasus pelarangan atau pembatasan aktivitas kegiatan ibadah kelompok tertentu ada 49 kasus (49\%), kemudian tindakan intimidasi dan ancaman kekerasan oleh aparat negara 20 kasus (20\%), pembiaran kekerasan 11 kasus (11\%), kekerasan dan pemaksaan keyakinan 9 kasus (9\%), penyegelan dan pelarangan rumah ibadah 9 kasus (9\%), dan kriminalisasi atau viktimisasi keyakinan 4 kasus (4\%). ${ }^{3}$ Pada tahun 2012 terjadi 274 kasus pelanggaran intoleransi dengan total $363 .{ }^{4}$ Lebih dari itu, selama JanuariDesember 2013, jumlah pelanggaran atau intoleransi sebanyak 245 kasus atau peristiwa, 106 peristiwa (43\%) melibatkan aktor negara dan 139 peristiwa (57\%) oleh aktor non-negara. Praktis, ada 280 kekerasan, dimana 121 tindakan

\footnotetext{
1Detiknews, "Massa FPI Bubar, Kemacetan di Depan Balai Kota Mencair" di dalam http://news. detik.com/read/2014/12/01/131509/2764008/10/, diakses pada tanggal 23 Desember 2014 .

2Mamang M. Haerudin, "Islam dan Potret Radikalisme," http://djavaspotblogspot.com/2014/ 02/islam-dan-potret-radikalisme.html,, diakses pada tanggal 2 November 2014.

3 Yenny Zannuba Wahid, "Lampu Merah Kebebasan Beragama: Laporan Kebebasan Beragama dan Toleransi di Indonesia 2011", http://www.wahidinstitute.org/wi-id/, diakses tanggal 27/01/ 2015.

${ }^{4}$ Laporan Tahunan The Wahid Institute 2012, http://www.wahidinstitute.org/wi-id/, diakses pada tanggal 23/01/2015.
} 
(43\%) dilakukan aktor negara dan 159 tindakan (57\%) oleh aktor nonnegara. ${ }^{5}$

Meski demikian, radikalisme atau fundamentalisme sesungguhnya sudah menjadi fenomena agama-agama diberbagai belahan dunia. Radikalisme atau fundamentalisme tidak hanya dilabelkan kepada penganut Islam, tetapi juga penganut agama lain seperti Kristen, Yahudi, Hindu dan Buddha. Fenomena radikalisme merupakan gejala yang terjadi di hampir semua agama, baik yang dapat menimbulkan kekerasan agama ataukah tidak. Kekerasan di dalam agama Hindu dapat dijumpai dalam kasus kekerasan agama di India Selatan, yaitu kaum Sikh haluan keras dengan Islam. Di Israel juga dijumpai kekerasan agama antara kaum Yahudi Utara dengan umat Islam. Di Jepang juga dijumpai kekerasan agama Shinto dalam bentuk penyimpangan agama yang mencederai lainnya. Demikian pula di agama Kristen seperti halnya yang terjadi di Amerika Serikat dan juga belahan Eropa lainnya. Di dalam Islam juga dijumpai kekerasan agama seperti terjadi berbagai teror baik yang langsung, maupun tidak langsung mencelakai orang lain. ${ }^{6}$

Deretan fenomena radikalisme, atau fundamentalisme dan intolerasi agama tersebut di atas, merupakan fakta yang sangat merisaukan, sekaligus menyedihkan. Indonesia sebagai Negara bangsa (nation state) yang mempunyai semboyan Bhinneka Tunggal Ika (berbeda-beda tetapi tetap satu jua) pun nyatanya tetap mempraktikkan kekerasan agama. Padahal, deradikalisasi agama telah, dan sedang berlangsung di pelbagai sektor pendidikan, tak terkecuali di pondok pesantren. Pondok Tremas Kabupaten Pacitan sebagai bagian dari pendidikan Islam pun menjadi salah satu pesantren yang selalu intens menyemaikan benih-benih deradikalisasi agama.

Pondok Tremas merupakan salah satu pondok tertua di Indonesia, didirikan oleh KH. Abdul Manan pada tahun 1828 di Desa Semanten sebelum pindah ke Desa Tremas, Kecamatan Arjosari. Di pondok inilah ajaran benih-benih toleransi, keadaban dan kemanusiaan tumbuh kembang hingga kini, bahkan berpartisipasi aktif dalam melakukan deradikalisasi agama. Sejak kelahirannya, Pondok Tremas telah mengalami enam kali estafet kepemimpinan, yakni:

\footnotetext{
5Laporan Tahunan The Wahid Institute 2013, http://www.wahidinstitute.org/wi-id/, diakses pada tanggal 23/01/2015.

${ }^{6}$ Nur Syam, "Radikalisme dan Masa Depan Hubungan Agama-agama: Rekonstruksi Tafsir Sosial Agama," makalah dipresentasikan dalam Pidato Pengukuhan Guru besar 10 Oktober 2005.
} 
pertama periode masa perintisan oleh KH. Abdul Manan (1830-1894). Kedua, periode pembangunan pada masa kepemimpinan KH. Abdullah (1862-1894). Ketiga, periode keemasan pada masa kepemimpinan KH. Dimyathi (18941934). Keempat, periode pembangunan, sekaligus era kemunduran pada kepemimpinan KH. Hamid Dimyathi (1934-1948). Kelima, periode kebangkitan berlangsung pada masa kepemimpinan KH. Habib Dimyathi, KH. Haris Dimyathi, KH. Hasyim Ikhsan (1948-1998). Keenam, periode kepemimpinan KH. Fuad Habib dan Lukman Hakim (1998-sekarang).

Poin terpenting yang harus diketahui adalah Pondok Tremas sejak kelahiran hingga kini senantiasa menentang radikalisme, atau fundamentalisme, sekaligus aktif melakukan deradikalisasi agama. Hanya saja, masing-masing periode kepemimpinan memiliki kebijakan dan strategi yang berbeda-beda atas penanganannya. Pokok permasalahan dalam penelitian ini difokuskan kepada dua hal, yaitu: (1) Bagaimana Pondok Tremas diera kepemimpinan KH. Fuad Habib dan Lukman Hakim melakukan deradikalisasi agama Islam? (2) Sejauhmana pula masa depan keberagaman di Kabupaten Pacitan?

Atas dasar latar belakang dan rumusan masalah tersebut, maka tujuan penelitian ini ditetapkan sebagai berikut, yakni: (1) untuk mengkaji dan menganalisis bagaimana Pondok Tremas di era kepemimpinan KH. Fuad Habib dan Lukman Hakim melakukan deradikalisasi agama Islam; (2) untuk mengkaji dan menganalisis sejauhmana pula masa depan keberagaman di Kabupaten Pacitan.

Penelitian ini memiliki dua kontribusi ilmiah, yaitu kontribusi teoritik dan kontribusi praktis. Secara teoritik, hasil riset ini dapat menambah media informasi, dan pengetahuan tentang deradikalisasi agama Islam di Pondok Tremas, khususnya, dan Kabupaten Pacitan pada umumnya. Secara praktis, penelitian ini diharapkan dapat memberikan kontribusi secara langsung bagi Pondok Pesantren Tremas dalam pembenahan pelaksanaan deradikalisasi agama Islam yang tengah berlangsung.

Metodologi penelitian yang digunakan dalam penelitian ini adalah pendekatan kualitatif, dengan menggunakan metode fenomenologi. Metode fenomenogis (phenomenological studies) mencoba mencari arti dari pengalaman dalam kehidupan. Peneliti menghimpun data berkenaan dengan konsep, pendapat, pendirian, sikap, penilaian, dan pemberian makna terhadap situasi atau pengalaman-pengalaman dalam kehidupan. Dalam pandangan fenomenologik, penelitian bermakna memahami peristiwa-peristiwa dalam kaitannya dengan 
orang dalam situasi tertentu. ${ }^{7}$ Hal ini dikarenakan bahwa fenomenologi merupakan strategi penelitian di mana di dalamnya peneliti mengidentifikasi hakikat pengalaman manusia tentang suatu fenomena tertentu.

\section{B. Akar Paham Radikalisme}

Kata radikal secara bahasa berasal dari bahasa Latin radix yang artinya akar (pohon). Radikalisme berarti secara mendalam dalam menelusuri suatu akar masalah. Jadi, pengertian radikal sebenarnya merujuk pada sesuatu yang positif (radic = akar), yaitu sesuatu yang mendasar (dalam terminologi Islam bisa berarti tauhid $=$ dasar Islam). Alih kata, radikalisme adalah gerakan yang berpandangan kolot dan sering menggunakan kekerasan dalam mengajarkan keyakinan mereka. ${ }^{8}$ Sedangkan orang yang radikal (radical, sebagai adjective) sebenarnya adalah orang yang mengerti sebuah permasalahan sampai ke akarakarnya, dan karena itu mereka lebih sering memegang teguh sebuah prinsip dibandingkan orang yang tidak mengerti akar masalah. ${ }^{9}$ Istilah radikal sinonim dengan istilah fundamentalis, yaitu umat Muslim yang menerima al-Qur'an dan Hadits sebagai jalan hidup mereka.

Ditilik dari perspektif geneologi radikalisme muncul dikarenakan beberapa penyebab, di antaranya yaitu: pertama, tekanan politik penguasa. Kedua, kegagalan rezim sekular dalam memusnakan kebijakan dan mengimplementasikannya di dalam kehidupan masyarakat. Ketiga, respons terhadap Barat.10 Akar paham radikalisme di Indonesia lebih dikarenakan faktor kemiskinan, korupsi, globalisasi, dan sejarah. ${ }^{11}$ Pandangan serupa disampaikan oleh Muhammad Tholhah Hasalan ${ }^{12}$, yang menilai munculnya gerakan radikalisme di Indonesia

\footnotetext{
7Moleong, Metodologi Penelitian Kualitatif, (Bandung: Remaja Rosda Karya), h. 23.

${ }^{8}$ Samsul Bahri, "Islam dan Wacana Radikalisme Agama Kontemporer", Jurnal Dinika, Vol. 3. No. 1, 2014, h. 23

${ }^{9}$ Suprihatiningsih, "Sprititualitas Gerakan Radikalisme Islam di Indonesia”, Jurnal Ilmu Dakwah, Vol. 32, No. 2, Juli-Desember 2012, h. 371.

${ }^{10}$ Nur Syam, "Radikalisme dan Masa Depan Hubungan Agama-Agama: Rekonstruksi Tafsir Sosial Agama”, makalah dipresentasikan dalam Pidato Pengukuhan Guru Besar, http://portalgaruda.org, diakses pada tanggal 10 November 2014.

${ }^{11}$ Christoper S. Bond dan Lewis M. Simons, "The Next Front: Southeast Asia and the Road to Global Peace with Islam”, dalam Ahmad Darmadji, "Pondok Pesantren dan Deradikalisasi Islam di Indonesia”, Jurnal Milah,Vol. XI, No 1, Agustus 2011, h. 244.

12Muhammad Tholhah Hasan, "Mozaik Islam Indonesia-Nusantara: Dialektika dan Keindonesiaan", dalam Ahmad Darmadji, "Pondok Pesantren dan Deradikalisasi Islam di Indonesia", Jurnal Milah,Vol. XI, No 1, Agustus 2011, h. 244.
} 
terutama setelah reformasi disebabkan variabel ajaran dan pemahaman, peranan media internet (IT), kondisi sosial domestik, dan konstalasi politik internasional.

Di sisi yang sama, istilah radikalisme Islam sesungguhnya berasal dari pers Barat untuk menunjuk gerakan Islam garis keras (ekstrem, fundamentalis, militan). Bahkan, istilah radikalisme dan fundamentalisme seringkali dikaitkan dengan sikap ekstrem, kolot, stagnasi, konservatif, anti Barat, dan keras dalam mempertahankan pendapat. ${ }^{13}$

Namun demikian, pada umumnya setidaknya ada dua alasan kenapa paham radikalisme berkembang, yakni: (1) mereka menolak sekularisme masyarakat Barat yang memisahkan agama dari politik, gereja dari negara. Kesuksesan Barat melakukan sekularisasi dianggap sebagai sesuatu yang berbahaya karena dapat mengancam Islam sebagai agama yang tidak hanya menggurusi ukhrawi, tetapi duniawi; (2) banyak umat Islam yang menginginkan agar masyarakat mereka diperintahkan dengan menggunakan al-Qur'an dan syariat Islam sebagai aturan bernegara. ${ }^{14}$

Selain istilah radikalislisme, ada berbagai istilah yang dipakai para pengamat dan sarjana untuk mengidentifikasi dan menjelaskan fenomena kebangkitan Islam di dunia Muslim, antara lain: revivalisme, militarisme, islamisme, Islam politik (political Islam), skripturalisme, dan ekstremisme. Menurut Syamsul Rijal, berbagai istilah tersebut, istilah fundamentalisme menjadi salah satu istilah yang sangat umum digunakan, baik oleh media, maupun akademisi. Akan tetapi, tidak semua sarjana sepakat dengan istilah ini, kerena mengandung makna pejoritif terhadap Islam. ${ }^{15}$

Poin terpenting yang perlu dipahami adalah bahwa paham radikalisme pada hakikatnya merupakan paham yang 'tercipta' atau sengaja diciptakan oleh kekuatan tertentu, khususnya 'Barat' untuk meligitimasi praduga (presumption), bahkan propaganda atas negara Islam. Islam radikal adalah istilah yang diberikan kepada kelompok-kelompok yang beraliran keras dalam menuntut penegakan

\footnotetext{
${ }^{13}$ Samsul Bahri, "Islam dan Wacana Radikalisme Agama Kontemporer", Jurnal Dinika, Vol. 3. No. 1, Januari 2014, h. 4. 2011.

${ }^{14}$ Junaidi Abdillah, "Dekonstruksi Tafsir Ayat-ayat Kekerasan”, Jurnal Analisis, Vol XI, No. 1, Juni

${ }^{15}$ Samsul Rijal, "Radikalisme Islam Klasik dan Kontemporer: Membanding Khawarij dan Hizbut Tahrir",Jurnal Al-Fikr, Vol. 14 No. 2, 2010, h, 216.
} 
syariat dengan jalan yang dianggap sebagai jihad. ${ }^{16}$ Praktek kekerasan yang seringkali ditampakkan oleh sejumlah kelompok-kelompok Islam tertentu terhadap simbol-simbol Barat tentunya tidak dapat digeneralisasi begitu saja, dan tidak bisa dianggap bahwa Islam itu identik dengan kekerasan.

Untungnya, kasus Islam phobia pasca peristiwa pengeboman gedung World Trade Centre di New York dan Pentagon pada 11 September 2001 lambat laun mulai reda. Pelan tapi pasti, labelisasi 'miring' atas dunia Islam pun berhenti. Hal ini nampaknya selaras dengan teori kultivasi, ${ }^{17}$ persoalan teroris, tak terkecuali radikalisme tidak lepas dari persepsi masyarakat terhadap media. Ketika media mem-blow up kasus radikalisme yang disangkutpautkan dengan Islam, maka masyarakat pun mempersepsikan demikian,sebagaimana kehidupan nyata sehingga menimbulkan ketakutan terhadap Islam. Sebaliknya, ketika media surut memberitakan aksi radikalisme Islam, otomatis ketakutan terhadap Islam pun terhenti.

\section{Stigma Radikalisme dalam Islam}

Gerakan radikalisme Islam sebenarnya merupakan "buah" dari pemahaman skripturalistik verbalis terhadap teks-teks keagamaan yang dipaksakan untuk meligitimasi "violence actions" dengan "menyeru jihad menebar teror" atas nama "Tuhan". ${ }^{18}$ Pemahaman skripturalis menganggap bahwa kebenaran hanya ada di dalam teks dan tidak ada kebenaran di luar teks. ${ }^{19}$

Stigma radikalisme juga pernah dialamatkan kepada gerakan kaum Khawarij di era sahabat Nabi Muhammad SAW. Tepatnya, muncul pada masa akhir pemerintahan Ali ibn Abi Thalib. Prinsip-prinsip radikal dan ekstrem dapat dilihat sebagai gerakan fundamentalisme klasik dalam sejarah Islam ini.

Langkah radikal mereka diabsahkan dengan semboyan lā hukma illā lillāh (tidak ada hukum kecuali bagi Allah) dan lā ḥukma illā Allāh (tidak ada hakim

\footnotetext{
16Suprihatiningsih, "Spiritualitas Gerakan Radikalisme Islam di Indonesia”, Jurnal Ilmu Dakwah, Vol. 32, No. 2 Juli 2012, h. 369.

17Lihat, Hafiidh, "Media dan Persepsi Masyarakat terhadap Islam", dalam http://blog.stikom.edu, diakses pada tangal 26 Januari 2015.

18A. Maftuh Abegebriel "Negara Tuhan: The Thematic Encyclopaedid" dalam Saifuddin, "Radikalisme Islam di Kalangan Mahasiswa(Sebuah Metamorfosa Baru)”, Jurnal Analisis, Vol. XI, No. 1, Juni 2011, h. 24.

${ }^{19}$ Saifuddin, "Radikalisme Islam di Kalangan Mahasiswa: Sebuah Metaforsa Baru”, Jurnal Analisis, Vol. XI, No. 1, Juni 2011, h. 25.
}

Walisongo, Volume 23, Nomor 1, Mei 2015 
selain Allah) yang dielaborasi berdasar QS. al-Ma'idah [5]: 44 yang berbunyi "wa man lam yaḥkum bimā anzalallāh faulāika hum 'l-kāfirūn" (siapa yang tidak menentukan hukum dengan apa yang diturunkan Allah, maka mereka adalah kafir). Dikarenakan alasan itulah maka kelompok Khawarij tidak mau tunduk kepada Ali dan Mu'awiyah. ${ }^{20}$

Sementara gerakan radikalisme Islam di Indonesia awal dapat dilacak dari adanya ide Negara Islam dan Tentara Islam Indonesia (DI/TII) dengan tokoh utama, SM. Kartosuwiryo. DI/TII diproklamasikan pada tanggal 17 Agustus 1949 di Jawa Barat. Tujuan utamanya adalah mendirikan negara berdasarkan Islam dan SM Kartosuwiryo sebagai imamnya.21

Pada tanggal 20 Januari 1952, DI/TII Kartosuwiryo mendapat dukungan dari Kahar Muzakkar dan pasukannya yang bermarkas di Sulawesi, kemudian pada tanggal 21 September 1953, Daud Beureueh di Aceh juga menyatakan bagian dari NII Kartosuwiryo. Pada tahun 1954, Ibnu Hajar dan pasukannya yang bermarkas di Kalimantan Selatan juga menggabungkan diri. Pada akhirnya, gerakan ini berhasil ditumpas oleh militer pro Pemerintah dan tidak pernah lagi muncul kecuali melalui gerakan bawah tanah. ${ }^{22}$

Harus diakui, dalam konstelasi politik Indonesia, kelompok pendukung radikalisme Islam semakin membesar tetapi gerakan radikal tersebut tidak memiliki pola yang seragam. Ada yang sekadar memperjuangkan implementasi syaria'at Islam tanpa keharusan mendirikan "Negara Islam", ada yang berusaha memperjuangkan berdirinya "kekhalifahan Islam". ${ }^{23}$ Belakangan ini, kelompok radikalisme juga bermetamorfosis melalui pelbagai lembaga pendidikan dan jama'ah pengajian.

Hanya saja, hingga kini 'sempalan' gerakan kelompok-kelompok radikalisme Islam di bidang pendidikan dan jam'iyyah (organisasi) pengajian tidak sevulgar induk semangnya. Bahkan, ia dikemas secara terstruktur dan sistematis. Objek sasarannya pun menyasar semua kalangan, khususnya di tingkat

\footnotetext{
${ }^{20}$ Azyumardi Azra, "Pergolakan Politik Islam", dalam Saifuddin, "Radikalisme Islam di Kalangan Mahasiswa: Sebuah Metaforsa Baru” Jurnal Analisis, Vol. XI, No. 1, Juni 2011, h. 20.

${ }^{21}$ Lihat: C. van Dijk "Rebellion Under the Banner of Islam: The Darul Islam in Indonesia", dalam Saifuddin, Jurnal Analisis, Vol. XI, No. 1, 2011, h. 26.

22Saifuddin, "Pergolakan Politik Islam", dalam Saifuddin, "Radikalisme Islam di Kalangan Mahasiswa: Sebuah Metaforsa Baru” Jurnal Analisis, Vol. XI, No. 1, 2011, h. 26.

${ }^{23}$ Suprihatiningsih, “Spiritualitas Gerakan Radikalisme Islam di Indonesia,” h. 369.
} 
stratifikasi sosial kelas menengah atas. Di area inilah tentunya digunakan sebagai salah satu strategi kaderisasi jangka panjang, melalui perubahan paradigma dan konseptual keislaman.

\section{Deradikalisasi Agama di Pondok Tremas}

Sebagai pondok pesantren tertua di Kabupaten Pacitan, sekaligus menjadi salah satu pondok tertua di Indonesia, Pondok Tremas senantiasa aktif melakukan tafaqquh fi 'l-dīn, sekaligus deradikalisasi agama (Islam). Deradikalisi agama yang dimaksud adalah upaya untuk menanamkan pemahaman agama yang ramah dan damai dalam perspektif kebhinekaan sehingga setiap pemeluk agama mau menerima perbedaan dengan wajar (tulus) dan lapang dada. ${ }^{24}$

Lebih-lebih, belakangan ini sejumlah jam'iyyah (organisasi) Islam acapkali bertindak radikal, dan cenderung melakukan praktik-praktik intoleransi atas nama agama Islam. Deradikalisasi agama Islam di Pondok Tremas dilakukan secara masif dengan pendekatan budaya. Pendekatan budaya yang dimaksud ialah praktik budaya keseharian di Pondok Tremas yang telah, sedang, dan akan senantiasa dilestarikan.

Praktik budaya Pondok Tremas yang dijadikan media perajut benih-benih deradikasi agama di Pondok Tremas, terdiri empat budaya, meliputi: (1) budaya keilmuan; (2) budaya keagamaan; (3) budaya sosial; dan (4) budaya politik. ${ }^{25}$ Lihat gambar 1.

Pada gambar tersebut, menunjukkan bahwa bagaimana praktik deradikalisasi agama Islam diimplementasikan di Pondok Tremas melalui lima budaya yang saling berkelindan satu dengan lainnya. Adapun penjelasan dari masingmasing praktik budaya di Pondok Tremas adalah sebagai berikut:

Pertama, budaya keilmuan Pondok Tremas. Budaya keilmuan di masingmasing pesantren pada hakikatnya berbeda-beda, tergantung pada keahlian (kepakaran) masing-masing si empunya pesantren -sang kiai- itu sendiri. Jika, sang kiai ahli di bidang ilmu Fiqh, Tauhīd dan Tasawuf misalnya, maka pesantrennya akan menitikberatkan pada domain bidang ilmu tersebut. Sebalik-

${ }^{24}$ Jeffrie Geovanie, "Deradikalisasi Agama," dalam Deradikalisasi Ajaran Agama: Urgensi, Problem dan Solusinya, http://stainmetro.ac.id/e-journal/index.php/akademika/article/view/, diakses pada tanggal 12 Februari 2015.

25Mukodi, "Studi Fenomenologi Pondok Tremas di Era Globalisasi", Disertasi, tidak diterbitkan, (Yogyakarta: Program Pascasarjana UNY, 2014), h. 211. 
nya, jika sang kiai ahli di bidang ilmu Naḥwu, Șaraf dan al-Qur'an, maka pesantrennya akan dikembangkan dalam keahlian yang dikuasainya pula.

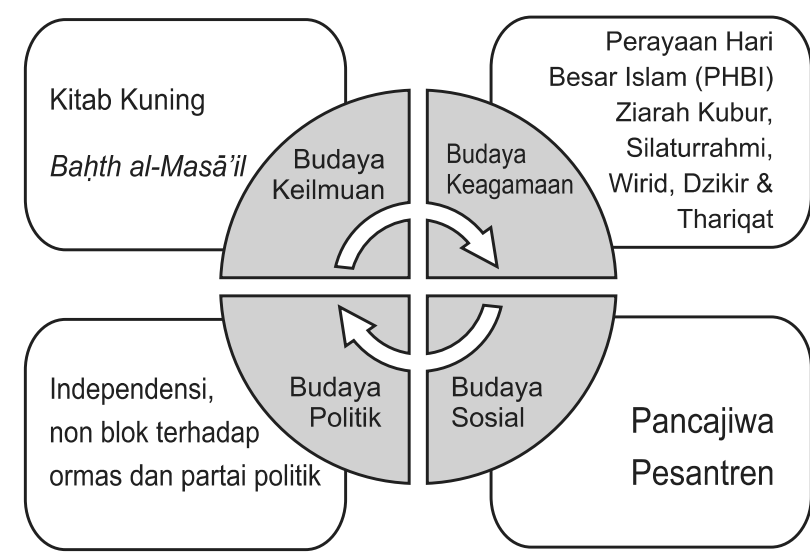

Gambar 1.

Praktik Deradikalisasi Agama di Pondok Tremas

Praktis, budaya keilmuan di suatu pesantren berkorelasi secara signifikan terhadap keahlian keilmuan yang dimiliki oleh sang kiai. Budaya keilmuan di Pondok Tremas terejawantahkan melalui pelbagai kajian kitab kuning dan bahth al-masāill. Tradisi kitab kuning pun menjadi salah satu cara untuk menemukan 'kebenaran' Tuhan. Alih kata, wahana untuk mendialogkan antara ayat-ayat qawliyyah (pesan-pesan al-Qur'an) dengan ayat-ayat kawniyyah (tanda-tanda alam semesta). Bukan hanya sekadar pengajaran teknis belaka, seperti membaca kitab, atau menghafal isi yang terkandung darinya.

Tradisi kitab kuning juga disebut sebagai great book, atau great tradition. Hal ini dikarenakan ia ditulis oleh ulama yang mumpuni (kompeten) di bidangnya, dan hidup dekat dengan tabi'in-tabi'in (generasi kekhalifahan Islam). Bahkan ada pula di antara mereka yang hidup sezaman dengan para sahabat Nabi Muhammad SAW.

Selain itu, budaya keilmuan juga selalu dilekatkan pada tradisi bahth almasā'il. Di zona inilah kajian-kajian kitab muktabarah (kitab-kitab terkenal) pun menjadi ajang kontestasi pencarian kebenaran universal atas pelbagai problema kehidupan masyarakat di akar rumput (grass root). Tradisi bahth almasā'il juga didasarkan pada sumber-sumber hukum Islam (al-Qur'an, Hadits, 
Ijmā', dan Qiyās). Beragam persoalan kehidupan diangkat, dan dicarikan solusinya, tak terkecuali terorisme, dan radikalisme agama.

Praktis, melalui pelbagai kajian bahth al-masă 'il, deradikalisasi agama Islam senantiasa disemaikan dan ditancapkan oleh keluarga besar Pondok Tremas. Kesalahan logika kaum radikalisme dan ekstremisme dalam memahami teks Alquran, maupun Hadits senantiasa diluruskan. Sebut saja, misalnya pemahaman pada ayat 29 Surat al-Taubah:

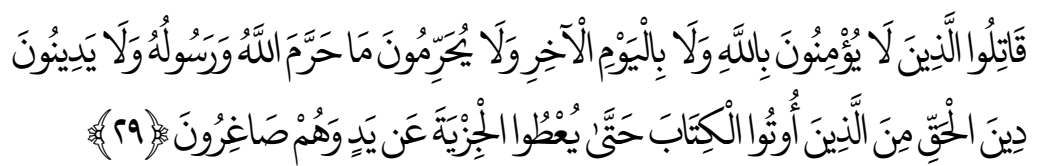

"Perangilah orang-orang yang tidak beriman kepada Allah dan tidak (pula) kepada hari Akhir, dan mereka tidak mengharamkan apa yang diharamkan oleh Allah dan Rasul-Nya dan tidak beragama dengan agama yang benar (agama Allah), (yaitu orang-orang) yang diberikan al-Kitab kepada mereka, sampai mereka membayar jizyah dengan patuh sedang mereka dalam keadaantunduk."26

Ayat tersebut di atas, dalam perspektif kaum radikalisme atau ekstremisme hanya dipahami secara take for granted (hanya terambil begitu saja), alias tekstualis an-sich. Lebih dari itu, mereka tidak melihat asbāb al-nuzūl (konteks turunnya ayat atau surat al-Qur'an), sehingga cenderung kaku, skripturalis dan tidak kontekstual. Padahal, semestinya tafsir Surat al-Taubah ayat 29 adalah "perangilah mereka, jika kalian diperangi terlebih dahulu, atau mereka mempunyai niat untuk menyerang kalian".

Lebih dari itu, dalam Tafsīr al-Marāghī diceritakan bahwa ayat ini adalah ayat pertama kali turun berkenaan dengan perang terhadap ahli Kitab (musyrik), karena ada sekelompok Nasrani yang merasa khawatir terhadap ajaran Muhammad, lalu mereka mengumpulkan pasukan dari suku Arab yang beragama Kristen dan bergabung dengan kekuasaan Romawi untuk menyerang kaum Muslim, sehingga orang Muslim merasa cemas terlebih setelah mereka mendengar bahwa pasukan sudah sampai di dekat Yordania. Kecemasan kaum Muslim tersebut dijawab oleh Allah dengan menurunkan ayat tersebut. ${ }^{27}$

\footnotetext{
${ }^{26}$ QS. al-Taubah [9]: 29.

${ }^{27}$ Ahmad Mustafa al-Maraghi, Tafsīr al-Marāghī, Jilid III, terj. Abdul Hamid al-Hasyimi, (Semarang: Toha Putra, 1981), hlm. 12.
} 
Kekeliruan kaum radikalisme atau ekstremisme selanjutnya yang diluruskan dalam budaya keilmuan di Pondok Tremas adalah pemahaman mereka terhadap surat al-Baqarah ayat 190:

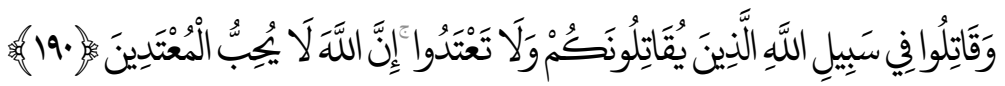

"Perangilah di jalan Allah mereka yang memerangi kamu, tetapi janganlah kamu melampaui batas (melanggar batas peri kemanusiaan), karena Allah tidak suka kepada orang-orang yang melampaui batas." ${ }^{28}$

Pemberian izin berperang pada ayat ini pada hakikatnya tidaklah mutlak, melainkan bersyarat bahwa peperangan itu haruslah karena faktor membela diri dan itu pun dengan syarat tidak melampaui batas kemanusiaan yang dapat menimbulkan kemarahan Allah SWT. Sehingga dalam konteks peperangan, jika ditinjau dari sejarahnya Islam memberikan dasar-dasar dalam peperangan membela diri, kehormatan, menjamin kelancaran dakwah dan menjamin kesempatan yang mau menganut Islam serta untuk menjaga sekaligus memelihara umat Islam dari serangan kekuatan Persia dan Romawi saat itu. ${ }^{29}$

Dengan demikian, jika kaum Muslimin -termasuk kaum radikalisme, atau ekstremisme- mengartikan al-Qur'an tanpa mencermati asbāb al-nuzūl dan tafsir al-Qur'an bisa saja keliru memahami teks tersebut. Dalam konteks itu, dalam sejumlah kesempatan keluarga besar Pondok Tremas pun senantiasa mengingatkan pentingnya atas hal itu. Adakalanya disampaikan secara formal dalam acara pelbagai kajian. Adakalanya, juga disampaikan secara informal pada saat para tamu, atau para santri yang sedang sowan ${ }^{30}$ ke dalem (rumah) sang kiai.

Berikut ini cuplikan kutipan KH. Lukman Hakim dalam acara informal saat penulis sowan ke rumahnya menanggapi persoalan jihad dan radikalisme yang berkembang di Indonesia:

“... Coba bayangkan, jika di Indonesia pemikiran orang Islam itu satu. Hanya syariat Islam, jihad untuk memerangi orang yang tidak Islam, maka Negara

${ }^{28}$ QS. al-Baqarah [2]: 190.

${ }^{29}$ A. Syalabi, Sejarah dan Kebudayaan Islam, sebagaimana dikutip oleh Junaidi Abdillah, "Dekonstruksi Tafsir Ayat-ayat Kekerasan", dalam Jurnal Analisis, Vol. 11, No. 1, Juni, 2011, h. 81.

${ }^{30}$ Tradisi turun temurun yang dilakukan oleh santri, atau masyarakat awam pada umumnya untuk menghadap atau bersilaturrahmi kepada sang kiai (keluarga kiai) di rumah kediamannya. Tujuannya bermacam-macam, diantaranya hanya sekadar bersilaturrahmi, atau meminta do'a atau nasihat sang kiai. Biasanya para tamu membawa buah tangan, berupa hasil pertanian atau semacamnya. 
Republik Indonesia bisa hancur, sebab isinya hanya berperang, utamanya yang beda keyakinan. ${ }^{31 "}$

Kutipan tersebut di atas, menunjukkan bahwa para kiai berserta keluarga besar Pondok Tremas sangat prihatin atas pelbagai aksi terorisme dan radikalisme sejumlah ormas yang mengatasnamakan agama belakangan ini. Deradikalisasi agama Islam pun dilaksanakan diberbagai kesempatan.

Kedua, budaya keagamaan. Budaya keagamaan di Pondok Tremas dibangun melalui sendi-sendi kehidupan bersama, meliputi praktik ubūdiyyah (penghambaan atau ibadah), sekaligus praktik 'amaliyyah (amalan-amalan keagamaan) secara simultan. Praktik budaya keagamaan di Pondok Tremas terejawantahkan melalui simpul-simpul pendidikan, pengajaran, maupun uswatun hasanah yang dipraktikkan oleh para pengurus, dewan guru, para kiai. Perayaan maulid Nabi Muhammad SAW. di setiap bulan Rabiul Awal, peringatan Isra' Mi'raj Nabi Muhammad SAW. di bulan Rajab, perayaan Tahun Baru Islam di setiap bulan Muharram dan peringatan haul pendiri pesantren merupakan deret budaya keagamaan yang terjadwal dari tahun ke tahun.

Tahlil, ziarah kubur, mujāhadah, istighāthah, manāqib-an, khatm al-qur'ān, perilaku zuhud, dalā'il adalah sisi lain dari praktik budaya keagamaan yang mentradisi secara temporal di pesantren yang di retas oleh KH. Abdul Manan, kakek dari Kiai Mahfud al-Turmusi ini. Praktis, budaya keagamaan tersebut, diciptakan, sekaligus diwariskan warga pesantren -kiai, keluarga kiai, santri dalem, pengurus pesantren, dan dewan guru- dari masa ke masa.

Poin terpenting yang harus diungkapkan adalah bahwa melalui budaya keagamaan tersebut, sesungguhnya deradikalisasi agama Islam tengah ditancapkan di Pondok Tremas. Melalui budaya keagamaan, para santri dan masyarakat diajarkan nilai-nilai toleransi, kebersamaan, penghargaan, dan keramah-tamahan. Keadaan yang demikian ini terbukti sangat efektif dalam menangkal, sekaligus meminimalisir paham radikalisme atau ekstremisme, baik di dalam pondok (internal), maupun di luar pondok (eksternal), masyarakat luas pada umumnya.

Ketiga, budaya sosial. Pancajiwa pesantren pada hakikatnya merupakan ruh kehidupan dari budaya sosial di Pondok Tremas. Pancajiwa pesantren 2014.

31Wawancara dengan KH. Lukman Hakim, salah satu pengasuh Pondok Tremas Pacitan, 12 Maret 
meliputi, jiwa keihlasan, jiwa kesederhanaan, jiwa kemandirian, jiwa $u k h u w$ wah islāmiyyah, dan jiwa kebebasan. Melalui budaya sosial inilah deradikalisasi agama Islam disemaikan dalam praktik keseharian warga pesantren. Gambaran budaya sosial dalam praktik tradisi kekeluargaan dan tolong-menolong antar santri dapat dilihat dalam cuplikan sebagai berikut:

Sebagian para santri di pondok pesantren tradisional (salafiyah) untuk memenuhi keperluan makan minum dalam keseharian mereka biasanya dilakukan dengan cara memasak yang dilakukan secara mandiri. Masak bersama adalah tradisi yang begitu dekat dengan kehidupan para santri. Ada kalanya dilaksanakan dengan bergilir, ada juga yang insidental. Ada yang terjadwal, ada pula yang tidak terjadwal. Umumnya dikerjakan di sela-sela waktu istirahat belajar. Baik di pagi hari, siang hari, maupun malam hari. Mereka memasak dan menyiapkan makanan mereka secara berkelompok-kelompok.

Lauk pauknya pun sangat sederhana, ada yang hanya memanfaatkan hasil kebun di lokasi pondok, seperti tanaman cabe, daun ketela, jantung pisang, ubiubian, pepaya, atau memanfaatkan sayur mayur masyarakat sekitar pondok, atau membeli lauk pauk sederhana di warung. Kebiasaan masak bersama tersebut, menjadikan para santri begitu sangat dekat, terjalin hubungan kekeluargaan dan saling memahami antar mereka, bahkan saling memahami kelebihan dan kekurangan mereka masing-masing. Nilai kebersamaan lainnya, tampak terlihat manakala ada santri yang bekal finansialnya (bahan masak; beras dan lauknya habis) dari rumah habis, maka dengan suka rela para santri tetap mengajak mereka makan bersama.

Nilai kebersamaan ini diwujudkan melalui tempat makan mereka, biasanya tatkala nasi yang dimasak sudah siap disajikan. Nasi beserta alakadar lauk pauknya pun, di pindahkan dari alat masak ke loyang/tampah -tempat makanan yang terbuat dari alumunium atau terbuat dari bambu yang berbentuk bundar, ukurannya sangat lebar bisa menampung kira-kira sepuluh sampai lima belas makanan santri- kemudian para santri secara berjama'ah makan secara lahap, sembari bergurau atau bercanda ala celotehan anak pondok. Akan tetapi, tradisi ini sekarang sulit ditemukan di pondok pesantren modern, karena dengan dalih efektivitas semua menu makanan sudah dibuatkan oleh pengelola pondok. ${ }^{32}$

32Mukodi, “Studi Fenomenologi Pondok Tremas di Era Globalisasi”, h. 277. 
Gambaran tersebut, menunjukkan budaya kekeluargaan pesantren tradisional (salafiyyah) Tremas sangat harmonis dan bersahaja. Hubungan kekeluargaan semacam itu, yang disebut Nurcholid Madjid sebagai pergaulan kehidupan di pesantren yang menjadi as the core of the pesantren. ${ }^{33}$ Lebih dari itu, kerja sama antara pondok dengan masyarakat dalam memperingati hari-hari besar agama Islam, misalnya kerja sama panitia peringatan nuzūl al-qur'an, serta takbir keliling bersama di hari raya Idul Adha. Bahkan, menurut Mukti Ali ciri-ciri pondok ditandai dengan adanya: (1) hubungan akrab antara santri dengan kiai; (2) ketaatan santri kepada kiai; (3) hidup hemat, sederhana; (4) semangat menolong diri sendiri; (5) persaudaraan dan saling membantu; (6) kedisiplinan; dan; (7) tahan menderita dalam meraih tujuan ${ }^{34}$. Tidak heran, jika Zamakhsyari Dhofier menandai lima unsur pokok pesantren, yakni pondok, masjid, santri, pengajaran kitab klasik, dan kiai.

Keempat, budaya politik. Dewasa ini, tidak sedikit pondok pesantren salafiyyah, maupun khalafiyyah di Indonesia yang berafiliasi dengan organisasi dan partai politik tertentu, sehingga cenderung menjadi 'corong' kepentingan. Namun demikian, hal itu tidak diikuti oleh Pondok Tremas. Bahkan, ia sejak kelahirannya (1828 M) hingga kini tidak terkooptasi dengan kepentingan mana pun.

Ia senantiasa mengajarkan budaya politik independen, yakni ketidakberpihakannya kepada partai politik, organisasi sosial, atau organisasi kemasyarakatan lainnya. Terpeliharanya tradisi independensi, non-blok akhirnya mendudukkan Pondok Tremas sebagai "rumah besar" bagi umat Islam. Praktis, semua kalangan masyarakat Islam dapat diterima dan menerima keberadaan Pondok Tremas. Kondisi inilah yang bermuara pada terbentuknya budaya politik yang khas itu sendiri. Berikut kutipan wawancara penulis dengan salah satu kiai di Pondok Tremas.

Muhammad Habib Dimyathi (salah satu putra Habib Dimyathi) menuturkan bahwa sebagai seorang kiai yang berpengaruh, ia (Gus Fuad) tentunya banyak sekali orang-orang, para politikus yang mengajaknya masuk ke jalur politik praktis, namun hal itu senantiasa ditolak secara halus oleh yang bersangkutan. Perlu diketahui, seolah sudah menjadi kesepakatan tidak tertulis, seorang yang ditunjuk sebagai pengasuh di Pondok Tremas, ia tidak diperkenankan berpihak pada partai, organisasi kemasyarakatan, maupun 19.

${ }^{33}$ Nurcholish Madjid, Bilik-bilik Pesantren: Sebuah Potret Perjalanan. (Jakarta: Paramadina, 1997), h.

${ }^{34}$ Mukti Ali, Metode Memahami Agama Islam, (Jakarta: Bulan Bintang, 1991), h. 6. 
golongan tertentu. Atas dasar itulah, sebagai pengasuh pondok hingga kini Gus Fuad selalu memegang prinsip tersebut. ${ }^{35}$

Dengan demikian, keempat bangunan budaya yang meliputi, budaya keilmuan; budaya keagamaan; budaya sosial; dan budaya politik tersebut di atas, sesungguhnya merupakan pilar-pilar yang sangat efektif dalam melaksanakan deradikalisasi agama Islam di Pondok Tremas. Apa yang dilakukan keluarga besar Pondok Tremas dalam melaksanakan deradikalisasi agama secara tidak langsung pun selaras dengan ide yang ditawarkan Peter L. Berger.

Menurut Peter L. Berger agar tidak terjadi kekerasan agama, dua hal harus dilakukan, yaitu: religious revolution dan religion subcultures. ${ }^{36}$ Arahan pertamanya terkait dengan bagaimana kaum elit agama dapat menumbuhkan dengan cepat kesadaran akan pentingnya model agama yang modern. Di dalam agama yang modern ditandai dengan cirinya yang menghargai pluralitas. Manusia tidak hidup dalam wilayah yang vakum diversitas dan vakum budaya. Manusia tidak hidup dalam ruang dan entitas homogin, tetapi manusia hidup di dalam ruang dan entitas heterogin. Dengan demikian, agama akan menjadi mode of communication, artinya agama menjadi model komunikasi tidak hanya vertikal kepada Tuhan, tetapi juga sebagai model komunkasi horizontal. ${ }^{37}$

Sementara itu, religion subcultures yang dimaksud laiknya subkultur yang digagas Abdurrahman Wahid yang memfilter pengaruh dari luar. Menurut Nur Syam, faktor politik dan ekonomi merupakan dua variabel penting yang sering mengintervensi kehidupan keberagaman. Akibatnya, banyak hal yang menjadi carut marut, karena faktor politik yang dimaksud. Padahal, agama sesungguhnya adalah persoalan moralitas, tertarik ke dalam wilayah politik dan ekonomi yang plofan. Implikasinya, adalah kesulitan untuk membedakan apakah ini masalah politik atau masalah agama. ${ }^{38}$

\footnotetext{
35Mukodi, "Studi Fenomenologi Pondok Tremas di Era Globalisasi”.

36Konsep religious dan religion subcultures, dinukil pada Nur Syam dalam makalah Pidato Pengukuhan Guru Besar, "Radikalisme dan Masa Depan Hubungan Agama-agama: Rekonstruksi Tafsir Sosial Agama”, http://portalgaruda.org/?...\%20Pidato\%20Pengukuhan\%20G, diakses pada tanggal 10 November 2014.

${ }^{37}$ Nur Syam, "Radikalisme dan Masa Depan Hubungan Agama-Agama: Rekonstruksi Tafsir Sosial Agama”, makalah dipresentasikan dalam Pidato Pengukuhan Guru Besar, http://portalgaruda.org, diakses pada tanggal 10 November 2014.

${ }^{38}$ Nur Syam, "Radikalisme dan Masa Depan Hubungan Agama-Agama: Rekonstruksi Tafsir Sosial Agama", makalah dipresentasikan dalam Pidato Pengukuhan Guru Besar, http://portalgaruda.org, diakses pada tanggal 10 November 2014.
} 
Dua hal tersebut di atas, sesungguhnya telah dipraktikkan secara konsisten oleh keluarga besar Pondok Tremas. Religious revolution dipraktikkan melalui budaya politik non-blok oleh para kiai. Di sisi yang sama, religion subcultures dipraktikkan melalui budaya keilmuan, budaya keagamaan, dan budaya sosial dalam keseharian warga pesantren.

\section{E. Masa Depan Keberagaman di Kabupaten Pacitan}

Masuknya agama Islam di wilayah Wengker Wetan, atau pesisir selatan yang kemudian bernama Pacitan, digambarkan dalam "Babad Pacitan" diperkirakan pada abad XVI. Hal ini berlangsung sejak Betara Katong Adipati Ponorogo, putra terakhir Raja Brawijaya memeluk Islam dan tunduk pada kekuasaan Islam di Demak Bintoro. ${ }^{39}$ Runtuhnya Kerajaan Majapahit tahun 1527 Masehi, kekuasaan pemerintahan Kerajaan Jawa pindah ke Demak (1478-156), kemudian ke Pajang (1546-1582), terakhir ke Mataram (1575-1745) dan masuknya nama Pacitan dalam catatan pemerintahan Sultan Agung Anyakrakusuma memperkuat bukti kesejarahan bahwa Islam masuk ke Pacitan di abab XVI.40

Pacitan pada masa Kerajaan Majapahit merupakan bagian dari wilayah Ponorogo, di era kekuasaan Adipati Betoro Katong. Pacitan dulu dikenal sebagai daerah Ponorogo bagian selatan, sedangkan Ponorogo sebelah utara adalah Kabupaten Ponorogo sebagaimana kondisi yang sekarang. Wilayah Pacitan kemudian menjadi tanah perdikan atau sima yang diberikan kepada Ki Ageng Buana Keling, keturunan bangsawan Pajajaran setelah mengawini putri Togati -putri raja Majapahit terakhir- dan diharuskan tunduk di bawah kekuasaan Majapahit. ${ }^{41}$

Secara demografis, Kabupaten Pacitan, merupakan satu dari 38 kabupaten di Jawa Timur yang terletak di selatan barat daya. Tepatnya, berbatasan dengan Kabupaten Ponorogo di utara, Kabupaten Trenggalek di timur, Samudera Hindia di selatan, dan Kabupaten Wonogiri di barat. Luas Wilayah Kabupaten Pacitan sebesar 1.389,872 km², terdiri atas 12 Kecamatan, 166 Desa, dan 5 Kelurahan.

\footnotetext{
${ }^{39}$ Gondowardoyo, Babad Pacitan, (Batavia: Balai Pustaka Batavia, 1935), h. 1-2.

40Pemda Pacitan, Hari Jadi Kabupaten Pacitan dalam Perspektif Sejarah Indonesia, (Pacitan: Pemda Pacitan, 1994), h. 14-15.

41Dimyathi, Mengenal Pondok Tremas dan Perkembangannya, ed. II, (Pacitan: Perguruan Islam Pondok Tremas, 2001), h. 18.
} 
Jumlah penduduk berdasarkan Sensus Penduduk Tahun 2010 (SP2010) mencapai 540.881 jiwa dengan kepadatan 400 jiwa/km2, dengan letak geografis berada antara $110^{0} 55^{\prime}-111^{0} 25^{\prime}$ Bujur Timur dan 70 55' - $8^{0} 17^{\prime}$ Lintang Selatan.

Kabupaten Pacitan berbatasan dengan wilayah-wilayah seperti terlihat pada gambar II. Adapun batas-batas administratif wilayah Kabupaten Pacitan adalah sebagai berikut: sebelah selatan berbatasan Samudera Indonesia, sebelah barat berbatasan Kabupaten Wonogiri (Jawa Tengah), sebelah utara berbatasan Kabupaten Ponorogo (Jawa Timur), dan sebelah timur berbatasan Kabupaten Trenggalek (Jawa Timur). ${ }^{42}$

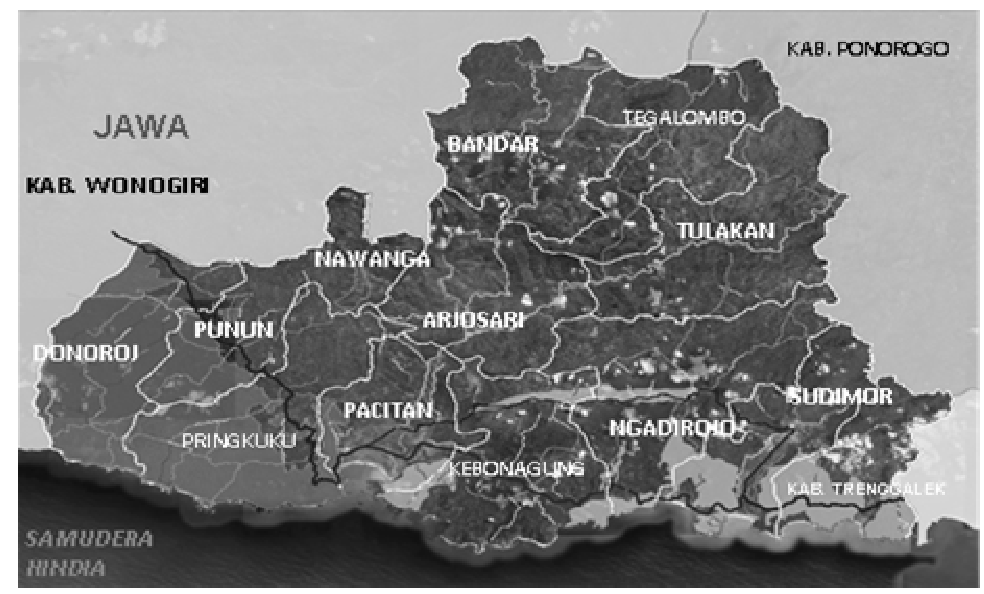

\section{Gambar 2.}

\section{Letak Kabupaten Pacitan}

Pola kehidupan dan budaya masyarakat pada umumnya mengikuti perkembangan manusia itu sendiri. Hal ini pun terjadi di masyarakat Pacitan, yang dikenal pula sebagai masyarakat berkota 1001 gua. Menurut A.G. Keller, berubah dan berkembangnya suatu kebudayaan berjalan menurut kebutuhan dari masyarakat yang bersangkutan dengan proses coba-coba (trial and error). Karena perubahan yang berjalan dengan cara penyesuaian diri dengan kebutuhan ini, maka kebudayaan sifatnya adaptif. ${ }^{43}$

\footnotetext{
42Laporan BBPS, “Pacitan dalam Angka 2013”, diakses pada tanggal 25 Februari 2014. h. Th.

${ }^{43}$ Soedjito, Aspek Sosial Budaya dalam Pembangunan Pedesaan, (Yogyakarta: Tiara Wacana, 1987),
} 
Dengan demikian, adanya kemungkinan akulturasi timbal balik antara Islam dan budaya lokal diakui dalam suatu kaedah atau ketentuan dasar dalam ilmu Ușul al-Fiqh, bahwa "Adat itu dihukumkan" (al-'adah muhakkamah), atau lebih lengkapnya, "Adat adalah syari'ah yang dihukumkan" (al-'adah shari'ah muhakkamah). Artinya, adat dan kebiasaan suatu masyarakat, yaitu budaya lokalnya, adalah sumber hukum dalam Islam. Namun demikian, tentunya adat dan budaya lokal tersebut tidak bertentangan dengan prinsip-prinsip Islam. Sedangkan unsur-unsur budaya yang bertentangan dengan prinsip Islam harus dihilangkan dan diganti. ${ }^{44}$

Mengacu pada teori sarjana Barat, sebagaimana dikutip oleh Bull ${ }^{45}$ masyarakat Muslim Indonesia dibagi menjadi dua kelompok besar, yaitu "tradisional", yang diasosiasikan dengan Nahdlatul Ulama (NU) dengan pondok pesantrennya, dan "modernis", yang diasosiasikan dengan Muhammadiyah. ${ }^{46}$ Pacitan yang merupakan kabupaten di wilayah Jawa Timur pun tidak terlepas dari polarisasi ideologi keagamaan. Hal ini dapat terlihat dari diagram berikut:

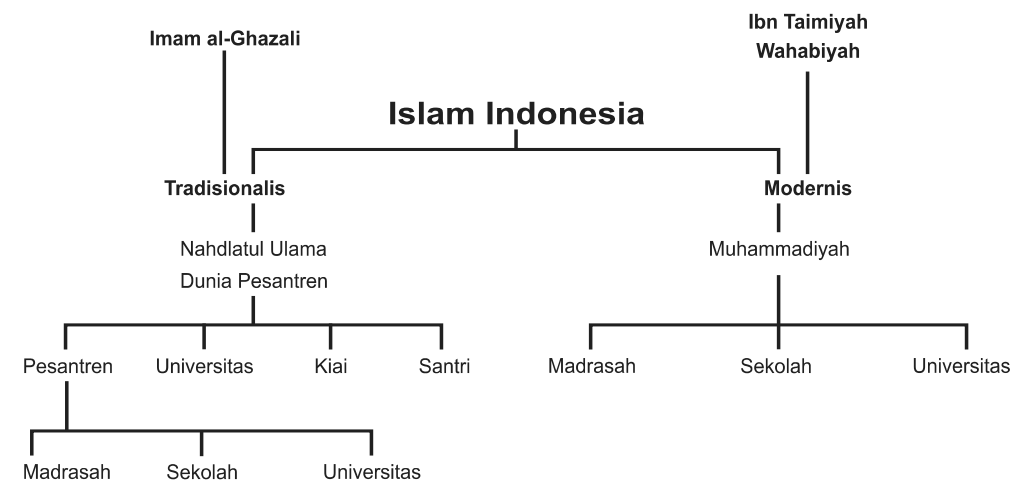

Gambar 3.

Islam di Indonesia: Pengaruh dan Aktivitasnya ${ }^{47}$

\footnotetext{
${ }^{44}$ Nurcholis Madjid, Islam dan Doktrin Peradaba, (Jakarta: Paramadina, 1992), h. 550.

${ }^{45}$ Ronald, "Madrasa by Any Other Name Pondok, Pesantren, and Islamic Schools in Indonesia and Larger Southeast Asian Region”. di dalam Jounal of Indonesian Islam, Vol. 24. No. 2010.

46Lihat, Ronald, "Madrasa by Any Other Name Pondok, Pesantren, and Islamic Schools in Indonesia and Larger Southeast Asian Region", di dalam Jounal of Indonesian Islam. Vol. 24. No. 2010, h. 13.

${ }^{47}$ Gambar tersebut diadaptasi dari Ronald, L.B., Jihad Ala Pesantren di Mata Antropolog Amerika, (Yogyakarta: Gama Media, 2004), h. 13.
} 
Polarisasi sebagaimana pada diagram tersebut, tentunya tidak dapat menggambarkan pelbagai paham keagamaan di Nusantara, tidak terkecuali di Kabupaten Pacitan. Kompleksitas keragaman keislaman di Indonesia tergambar lebih jelas dari hasil penelitian Norhaidi dalam "Laskar Jihad". Selain berkembangnya ormas Muhammadiyah, Nahdlatul Ulama (NU), dan Nahdlatul Waton, Komite Indonesia untuk Solidaritas Dunia Islam (KISDI), Jama'ah Ikhwanul Muslimin Indonesia (JIMI), Hizbut Tahrir Indonesia (HTI), Kesatuan Aksi Mahasiswa Muslim Indonesia (KAMMI), dan Himpunan Aksi Mahasiswa Muslim Antar kampus (Hammas) pun tumbuh subur di berbagai wilayah.48

Namun demikian, pada umumnya, sesuai dengan karakteristik masyarakat perdesaan, Pacitan sebagai kota kecil, berpenduduk 540.516 orang yang mayoritas bergama Islam, menjadikan Nahdlatul Ulama sebagai organisasi keagamaannya. Di samping itu, ada pula warga masyarakat yang bernaung dalam panjipanji ormas Muhammadiyah, dan Majelis Tafsir Al-Qur'an (MTA), Lembaga Dakwah Islam Indonesia (LDII), tetapi jumlahnya tidak banyak.

Dalam konteks itu, keragaman dalam beragama di Kabupaten Pacitan hingga artikel ini diretas tergolong sangat baik. Buktinya, selama sepuluh tahun terakhir tidak ada kekerasan atas nama agama yang berlangsung. Jika ditelisik lebih jauh, hal itu dikarenakan empat faktor yang saling komplementer, yakni: 1) tipologi masyarakat Pacitan yang masih menjaga nilai-nilai budaya Jawa; 2) letak geografis, dan topografi Pacitan yang curam, berbatu, dan bergunung berkorelasi positif terhadap karakter penduduk; 3) eksistensi Pondok Pesantren Tremas, khususnya dan pondok pesantren lainnya di Kabupaten Pacitan dalam menetralisir paham-paham anarki, dan radikal; 4) pemerintah Kabupaten Pacitan yang mampu menjaga dan mengayomi seluruh warganya berdampak positif terhadap toleransi, dan kebersamaan antar warga masyarakat.

Mencermati keempat faktor tersebut di atas, jelaslah bahwa penyebab keberagaman teretas dengan baik di Kabupaten Pacitan dikarenakan keempat elemen itu yang saling melengkapi dan mengisi, sehingga kerukunan antar warga, baik sesama agama, maupun beda agama dapat terwujud dengan baik.

Lebih-lebih, keluarga besar Pondok Tremas yang senantiasa aktif melakukan berbagai kegiatan sosio-keagamaan, pendidikan, dan budaya salafiyah

\footnotetext{
${ }^{48}$ Norhaidi Hasan, Laskar Jihad: Islam, Militancy and the Quest for Identity in Post-New-Order Indonesia, (New York: Cornell South-east Asia Program Publication, 2008), h. 14.
} 
kepesantrenan cukup strategis dalam menjaga kedamaian, dan peradaban kota yang dikenal sebagai Kota Seribu Satu Gua ini. Jadi, masa depan keberagaman di Kabupaten Pacitan tetap terjaga. Dengan demikian, Pacitan tetap menjadi hunian yang nyaman bagi kehidupan manusia.

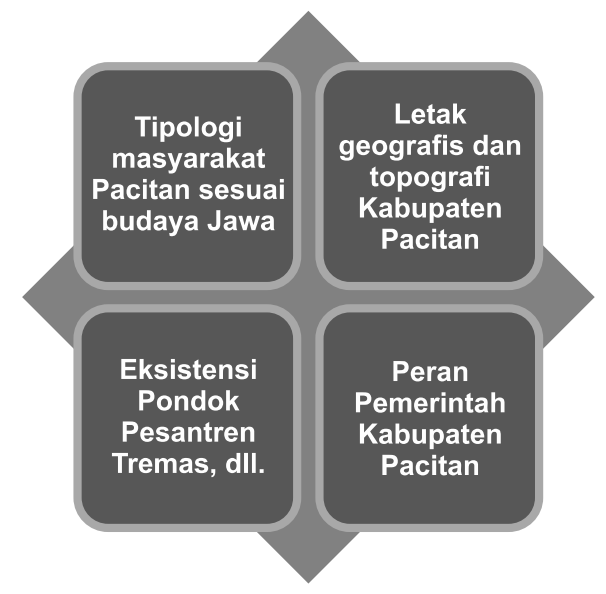

Gambar 4.

Penyebab Keberagaman Tersemai di Kabupaten Pacitan

\section{F. Kesimpulan}

Gerakan radikalisme di Indonesia lebih dikarenakan oleh faktor kemiskinan, korupsi, globalisasi, dan sejarah. Lebih dari itu, variabel ajaran dan pemahaman, peranan media internet (IT), kondisi sosial domestik, dan konstalasi politik internasional turut andil dalam mempolarisasi tindak intoleransi beragama. Agar dapat meredam, sekaligus memotong akar radikalisme tersebut, hendaknya masing-masing variabel pemicunya harus dipangkas. Namun demikian, hal itu tentu sangat sulit, -kalau tidak dikatakan- mustahil. Hanya saja, pelbagai upaya penghambatan, dan peminimalisiran gerakan radikalisme harus disemaikan tanpa henti.

Pondok pesantren, sebagai lembaga pendidikan dan sosial keagamaan tertua di Indonesia pun mengambil peranan strategis, tak terkecuali Pondok Tremas di Kabupaten Pacitan. Dibawah kepemimpinan KH. Fuad Habib dan Lukman Hakim,Pondok Tremas senantiasa aktif melakukan deradikalisasi agama. Praktik budaya keseharian warga pesantren yang terejawantahkan 
melaui budaya keilmuan, budaya keagamaan, budaya sosial, dan budaya politik merupakan tindakan nyata dari hal itu.

Praktis, masa depan keberagaman di Kabupaten Pacitan hingga kini cukup stabil. Hal itu dikarenakan adanya empat faktor, yakni: (1) tipologi masyarakat Pacitan yang masih menjaga nilai-nilai budaya Jawa; (2) letak geografis, dan topografi Pacitan yang curam, berbatu, dan bergunung berkorelasi positif terhadap karakter penduduk; (3) eksistensi Pondok Pesantren Tremas, khususnya dan pondok pesantren lainnya di Kabupaten Pacitan dalam menetralisir paham-paham anarki, dan radikal; (4) pemerintah Kabupaten Pacitan yang mampu menjaga dan mengayomi seluruh warganya berdampak positif terhadap toleransi, dan kebersamaan antar warga masyarakat.[w] 


\section{BIBLIOGRAFI}

Abegebriel, A. Maftuh, "Negara Tuhan: The Thematic Encyclopaedia" dalam Saifuddin, "Radikalisme Islam di Kalangan Mahasiswa (Sebuah Metamorfosa Baru)", Jurnal Analisis, Vol. XI, No. 1, Juni 2011.

Abdillah, Junaidi, "Dekonstruksi Tafsir Ayat-ayat Kekerasan", dalam Jurnal Analisis, Vol. 11, No. 1, Juni, 2011.

Ali, Mukti, Metode Memahami Agama Islam, Jakarta: Bulan Bintang, 1991.

Bahri, Samsul, "Islam dan Wacana Radikalisme Agama Kontemporer", Jurnal Dinika, Vol. 3. No. 1, Januari 2014.

Christoper S. Bond dan Lewis M. Simons, "The Next Front: Southeast Asia and the Road to Global Peace with Islam", dalam Ahmad Darmadji, "Pondok Pesantren dan Deradikalisasi Islam di Indonesia”, Jurnal Milah, Vol. XI, No 1, Agustus 2011.

C. van Dijk "Rebellion Under the Banner of Islam: The Darul Islam in Indonesia", dalam Saifuddin, Jurnal Analisis, Vol. XI, No. 1, Juni 2011.

Gondowardoyo, Babad Pacitan, Batavia: Balai Pustaka Batavia, 1935.

Hasan, Norhaidi, Laskar Jihad: Islam, Militancy and the Quest for Identity in PostNew-Order Indonesia, New York: Cornell South-east Asia Program Publication, 2008.

Hasan, Muhammad Tholhah, "Mozaik Islam Indonesia-Nusantara: Dialektika dan Keindonesiaan", dalam Ahmad Darmadji, "Pondok Pesantren dan Deradikalisasi Islam di Indonesia", Jurnal Milah, Vol. XI, No 1, Agustus 2011.

Madjid, Nurcholish, Bilik-bilik Pesantren: Sebuah Potret Perjalanan, Jakarta: Paramadina, 1997.

Madjid, Nurcholish, Islam dan Doktrin Peradaban, Jakarta: Paramadina, 1992.

al-Maraghi, Ahmad Mustafa, Tafsir al-Maraghi, Jilid III, terjemahan Abdul Hamid al-Hasyimi, Semarang: Toha Putra, 1981.

Mukodi, "Studi Fenomenologi Pondok Tremas di Era Globalisasi", Disertasi, tidak diterbitkan, Yogyakarta: Program Pascasarjana UNY, 2014.

Moleong, L. Metodologi Penelitian Kualitatif, Bandung: Remaja Rosda Karya, 2014.

Pemda Pacitan, Hari jadi Kabupaten Pacitan dalam Perspektif Sejarah Indonesia, Pacitan: Pemda Pacitan, 1994.

Walisongo, Volume 23, Nomor 1, Mei 2015 
Dimyathi, Mengenal Pondok Tremas dan Perkembangannya, ed. II, Pacitan: Perguruan IslamPondok Tremas, 2001

Ronald, "Madrasa by Any Other Name Pondok, Pesantren, and Islamic Schools in Indonesia and Larger Southeast Asian Region," dalam Jounal of Indonesian Islam, Vol. 24. No. 2010.

Ronald, L.B., Jihad Ala Pesantren di Mata Antropolog Amerika, Yogyakarta: Gama Media, 2004.

Rijal, Samsul, "Radikalisme Islam Klasik dan Kontemporer: Membanding Khawarij dan Hizbut Tahrir", Jurnal Alfikr, Vol. 14 No. 2, 2010.

Saifuddin, "Radikalisme Islam di Kalangan Mahasiswa: Sebuah Metaforsa Baru", Jurnal Analisis, Vol. XI, No. 1, Juni 2011.

Suprihatiningsih, "Sprititualitas Gerakan Radikalisme Islam di Indonesia", Jurnal Ilmu Dakwah, Vol. 32, No. 2, Juli-Desember 2012.

Soedjito, Aspek Sosial Budaya dalam Pembangunan Pedesaan, Yogyakarta: Tiara Wacana, 1987.

\section{Internet:}

Geovanie, Jeffrie,“Deradikalisasi Agama,” dalam “Deradikalisasi Ajaran Agama: Urgensi, Problem dan Solusinya”, http://stainmetro.ac.id/e-journal/index. php/akademika/article/view/, diakses tanggal 12 Februari 2015.

Haerudin, Mamang, "Islam dan Potret Radikalisme", http://djavaspot.blogspot. com/2014/02/islam-dan-potret radikalisme.html., diakses tanggal 2 November 2014.

Hafiidh, "Media dan Persepsi Masyarakat terhadap Islam", http://blog.stikom .edu, diakses pada 26 Januari 2015.

Laporan BBPS, “Pacitan dalam Angka 2013”, diakses pada tanggal 25 Februari 2014.

Nur Syam, "Radikalisme dan Masa Depan Hubungan Agama-agama: Rekonstruksi Tafsir Sosial Agama", makalah dipresentasikan dalam Pidato Pengukuhan Guru Besar, http://portalgaruda.org, diakses pada tanggal 10 November 2014.

Wahid, Yenny Zannuba, "Lampu Merah Kebebasan Beragama: Laporan Kebebasan Beragama dan Toleransi di Indonesia 2011", http://www. wahidinstitute.org/ wi-id/, diakses tanggal 27/01/ 2015. 